\title{
Preparation and characterization of microparticles loaded with seed oil of Caatinga passion fruit obtained by spray drying
}

\author{
Preparação e caracterização de micropartículas encapsuladas com óleo de semente de \\ maracujá da Caatinga obtidas por secagem por atomização
}

\begin{abstract}
Jocilane Pereira de Oliveira ${ }^{1}$, Lívia Alves Barroso ${ }^{1}$, Ana Júlio ${ }^{2,3}$, Rita Caparica ${ }^{2,3}$, Maria Josiane Macedo ${ }^{1}$, Fabiane Neves Silva ${ }^{1}$, Michelle Guimarães Horta ${ }^{1}$, José Fábio Soares ${ }^{4}$, Tânia Santos de Almeida ${ }^{2}$, Álvaro Júnior ${ }^{1}$, Guilherme Carneiro ${ }^{1}$, Pedro Fonte ${ }^{2,5,6}$, Joyce Maria Gomes da Costa ${ }^{1}$

${ }^{1}$ Universidade Federal dos Vales do Jequitinhonha e Mucuri, Campus JK, Rodovia MGT 367-Km 583, n 5000, 39100-000 Diamantina- MG, Brazil

${ }^{2}$ CBIOS-Universidade Lusófona's Research Center for Biosciences \& Health Technologies, Campo Grande 376, 1749-024 Lisboa, Portugal ${ }^{3}$ Department of Biomedical Sciences, University of Alcalá, Ctra. Madrid-Barcelona Km. 33.600, 28871 Alcalá de Henares, Madrid, Spain.

${ }^{4}$ Universidade Federal de Minas Gerais, Campus Regional de Montes Claros, Avenida Universitária, 1000, Bairro Universitário Montes Claros, MG, 39404-547, MG, Brazil

${ }^{5}$ LAQV, REQUIMTE, Department of Chemical Sciences - Applied Chemistry Lab, Faculty of Pharmacy, University of Porto, Rua de Jorge Viterbo Ferreira, 228, 4050-313 Porto, Portugal

${ }^{6} \mathrm{iBB}-I n s t i t u t e$ for Bioengineering and Biosciences, Department of Bioengineering, Instituto Superior Técnico, Universidade de Lisboa, 1049-001 Lisboa, Portugal

Email: joyce.costa@ict.ufvjm.edu.br
\end{abstract}

\begin{abstract}
The aim of this work was the development and characterization of microparticles of seed oil from the passion fruit of the Caatinga (Passiflora cincinnata). Microencapsulation is a good strategy for preservation of oils as it protects bioactive components from deteriorating factors and limits the loss of volatile substances. The drying method used was a spray dryer, using modified starch, arabic gum, and maltodextrin as the encapsulating materials. The microparticles were characterized with respect to the moisture content, water activity (Aw), physicochemical properties, and morphology. The samples showed an Aw of approximately 0.10 and moisture of $1.03 \%$, which are relatively common in powders produced by spray drying. The microparticles had spherical shape with diameter of approximately $23.1 \pm 0.05 \mu \mathrm{m}$, both of which were influenced by the process parameters. The microparticles showed the particle spread, calculated as span, was $1.56 \pm 0.03$, which is typical of the type of atomizer used (double-fluid). The particles loaded with seed oil from the passion fruit of the Caatinga were successfully produced by spray drying and the characterization showed low values of Aw, moisture content, diameter, spherical shape, and the value of span showed a homogeneous particle size distribution. The results are promising and suitable for future applications that contribute to development of food and cosmetics products.
\end{abstract}

Keywords: Microparticle; Spray-drying; Passion fruit; Caatinga; Seed Oil.

\section{Resumo}

O objetivo deste trabalho foi a preparação e caracterização de micropartículas de óleo de semente do maracujá da Caatinga (Passiflora cincinnata). A microencapsulação é uma boa estratégia para a preservação de óleos, uma vez que protege os bioativos de fatores que levam à sua detioração e limita a perda de substâncias voláteis. O método de secagem utilizado foi a secagem por atomização, utilizando amido modificado, goma arábica e maltodextrina como material de encapsulação. As micropartículas foram caracterizadas quanto ao teor de humidade, atividade de água (Aw), propriedades físico-químicas e morfologia. As amostras apresentaram uma Aw de cerca de 0,10 e mistura de $1,03 \%$, que são valores relativamente comuns em pós produzidos por secagem por atomização. As micropartículas apresentaram um formato esférico com diâmetro de cerca de $23,1 \pm 0,05 \mu \mathrm{m}$, que foi influenciado pelos parâmetros da técnica. As micropartículas mostraram uma dispersão de partículas, calculada usando o span de 1,56 $\pm 0,03$, que é típico do tipo de atomizador usado (duplo fluido). As partículas carregadas com o óleo de semente do maracujá da Caatinga por secagem de atomização foram produzidas com sucesso e a sua caracterização apresentou baixos valores de Aw, humidade, diâmetro, forma esférica e o valor de span apresentou distribuição homogénea quanto ao tamanho de partícula. Os resultados obtidos são promissores e adequados para aplicações futuras que contribuam para o desenvolvimento de novos produtos alimentares e cosméticos.

Palavras chave: Micropartícula; Secagem por atomização; Maracujá; Caatinga; Óleo de semente. 


\section{Introduction}

The Caatinga passion fruit (Passiflora cincinnata) is one of the passion fruit species native to the semi-arid regions of the northeast of Brazil (1). Due to its phytochemical properties, such as antioxidant activity and its characteristic flavour (2), there has been a growing interest in this species from food, cosmetic, and pharmaceutical industries $(1,2)$. Both in Brazil and abroad, the fruit peel can be processed in the form of flour and other by-products. The "waste solids" of this fruit are mainly composed of seeds, which have a moisture content of around $14 \%$. Despite the fact that these seeds represent only $4.23 \%$ of the fruit's weight, they are a worthy source of useful oil. The high content of total polyphenols and total antioxidant activity indicate the seeds as a natural source of bioactive compounds $(1,3)$. The oil extracted from these passion fruit seeds contains a high percentage of fatty acids, which may represent a benefit to gain from these compounds. More precisely, the seeds of the Caatinga passion fruit are composed of 69.2 to $76.6 \%$ of linoleic fatty acid and 12.0 to 24.8 $\%$ of oleic acid. This higher content of unsaturated fatty acids explains the low oxidation stability of its oil, which limits its application in different products (4) In this context, it is necessary to find alternatives, such as the microencapsulation technique, to increase the oil stability.

Microencapsulation is a technique used to protect liquids, solids, or gases using polymer encapsulation $(5,6)$. Its purpose is to protect a compound from environmental factors while enhancing the release, the stability, and efficiency of the loaded substances (5). This technique may be performed using chemical, physical, or physicochemical methods, such as spray dryer (5).

In the food industry, spray drying is an economical, flexible, and widely-used process for microencapsulation in which atomized particles come into contact with the air, which causes the water within to evaporate and thus produce dry particles (7).

Concerning the microencapsulation of food ingredients, the choice of the encapsulating materials is a key factor, since an inadequate choice may lead to increased degradation of the central compound and make incorporation into the food matrix impossible $(8,9)$

Hence, the aim of this work was to develop and characterize microparticles produced through the spray dryer method, using modified starch, arabic gum, or maltodextrin, as encapsulating materials to load the seed oil from the Caatinga passion fruit towards a future application in food products.

\section{Introdução}

O maracujá da caatinga (Passiflora cincinnata) é uma das espécies de maracujá nativa das regiões semiáridas do Nordeste do Brasil (1). Devido às suas propriedades fitoquímicas, como a atividade antioxidante, e seu sabor característico (2), tem havido um interesse crescente por esta espécie, por parte das indústrias alimentar, cosmética e farmacêutica $(1,2)$. O uso desta fruta pela indústria pode permitir uma redução do resíduo sólido, resultante do seu processamento. Apesar da grande quantidade de resíduos sólidos resultante ser composta principalmente por sementes, o que representa 4,23\% do peso da fruta e apresenta um teor de humidade de cerca de $14 \%$, estas sementes ainda representam uma fonte valiosa de óleo utilizável. Tanto no Brasil como em outros países, a casca de frutas pode ser processada na forma de farinha e outros subprodutos. Devido ao alto teor de polifenóis totais e atividade antioxidante total indicam uma fonte natural de compostos bioativos $(1,3)$.

O óleo extraído das sementes de maracujá contém elevada percentagem de ácidos gordos, o que pode representar um benefício a ser extraído desses resíduos. Mais precisamente, as sementes do maracujá da Caatinga apresentam na sua composição 69,2 a 76,6 \% de ácido gordo linoleico e 12,0 a 24,8 \% de ácido oleico. Este elevado teor de ácidos gordos insaturados leva a que este óleo tenha uma baixa estabilidade oxidativa limitando sua aplicação em diferentes produtos (4). Neste contexto, é necessário encontrar alternativas para aumentar a estabilidade do óleo, como a técnica de microencapsulação.

A microencapsulação é uma técnica usada para proteger líquidos, sólidos ou gases através da encapsulação de polímero $(5,6)$. O objetivo desta técnica é proteger um composto de fatores ambientais, aumentando a libertação, a estabilidade e a eficiência das substâncias encapsuladas (5). Esta técnica pode ser efetuada por métodos químicos, físicos ou físico-químicos, como a secagem por atomização (5).

$\mathrm{Na}$ indústria alimentar, a secagem por atomização é amplamente utilizada para microencapsulação, na qual as partículas atomizadas entram em contato com o ar, fazendo com que ocorra a evaporação da água e, consequentemente a produção de partículas secas, tornando-a um processo económico e flexível (7). A parede externa da micropartícula é utilizada para, evitar a interação do núcleo com outros compostos, de forma a protege-lo de fatores que possam causar a sua deterioração (luz, humidade e calor), para limitar a perda de substâncias 


\section{Materials and Methods}

\section{Materials}

Cold-extracted seed oil of the Caatinga passion fruit was obtained from the "Cooperativa dos Agricultores Familiares e Agroextrativistas Grande Sertão Montes" Claros-MG, Brazil, and used as a bioactive. The encapsulating materials used were arabic gum from Metachem Industrial and Comercial Ltda. (Consolação, SP, Brazil), maltodextrin MOR-REX ${ }^{\circledR} 1920$ from Tradal Brazil Com. Imp. Exp, Ltda (Jandira, SP, Brazil) and modified starch (Dextrin Capsul ${ }^{\circledR}$ ) provided by Ingredion Incorporated (Westchester, IL, United States of America (USA)).

\section{Preparation of the oil-in-water $(\mathrm{O} / W)$ emulsion}

First, $25.0 \mathrm{~g}$ of arabic gum, $37.5 \mathrm{~g}$ of modified starch and $37.5 \mathrm{~g}$ of maltodextrin were hydrated in $100 \mathrm{~g}$ of deionized water $(10,11)$ for approximately 12 hours under refrigeration $\left(10-12{ }^{\circ} \mathrm{C}\right)$. The mixture was then dissolved in $450 \mathrm{~mL}$ of deionized water at $60-70{ }^{\circ} \mathrm{C}$ using a Turratec homogenizer TE 102 (Tecnal Scientific Equipments, Piracicaba, SP, Brazil) at 20,000 rpm for 15 minutes. After the complete solubilization of the encapsulating materials, the temperature of the homogenizer was lowered to $18{ }^{\circ} \mathrm{C}$ and $5 \mathrm{~mL}$ of the seed oil of the Caatinga passion fruit of was added, with a rotor speed of 20,000 rpm for 5 minutes, until the O/W emulsion was obtained.

\section{Spray drying of the microparticles}

The prepared $\mathrm{O} / \mathrm{W}$ emulsion was spray dried using a MSD 0.5 LABMAQ (Ribeirão Preto, SP, Brazil) atomizer, with a double fluid nozzle spraying system with a $0.7 \mathrm{~mm}$ opening. The operating conditions of the atomizer were chosen after performing preliminary tests, with the inlet air temperature set to $120 \pm 3{ }^{\circ} \mathrm{C}$, the feed flow rate adjusted to $30 \mathrm{~L} \mathrm{~min}^{-1}$, and the air flow inlet maintained at $0.50 \mathrm{~L} \mathrm{~h}^{-1}$. The compressed air pressure to the spray flow was 2-4 bar. The powder produced was stored in an amber glass vial to minimize possible changes in the material, such as agglomeration, caused by water adsorption and oxidation.

\section{Water Activity (Aw) and moisture content}

The Aw was measured by direct reading of the samples in triplicate in an Aqualab 4TE water activity meter (Meter Group, Pullman, WA, USA), at a controlled temperature of $18 \pm 0.5^{\circ} \mathrm{C}$. The moisture content was evaluated by the gravimetric method, in triplicate, at voláteis, possibilitar uma libertação controlada do ativo encapsulado e mascarar sabores indesejáveis.

Relativamente à microencapsulação de ingredientes alimentares, a escolha dos materiais de encapsulação é um fator muito importante, uma vez que a escolha inadequada pode levar a uma maior degradação do composto a encapsular e impossibilitar a sua incorporação na matriz alimentar $(8,9)$.

Desta forma, o objetivo deste trabalho foi desenvolver e caracterizar micropartículas produzidas pelo método de secagem por atomização, utilizando amido modificado, goma arábica ou maltodextrina, como materiais de encapsulação para incorporar o óleo de semente, proveniente do maracujá da Caatinga, tendo como finalidade uma futura aplicação em produtos alimentares.

\section{Materiais e Métodos}

\section{Materiais}

O óleo de semente de maracujá da Caatinga foi extraído a frio e obtido da Cooperativa dos Agricultores Familiares e Agroextrativistas Grande Sertão Montes, em Claros-MG, Brasil, e utilizado como bioativo. Os materiais de encapsulação utilizados foram a goma arábica da Metachem Industrial and Comercial Ltda. (Consolação, SP, Brasil), maltodextrina MOR-REX ${ }^{\circledR} 1920$ da Tradal Brazil Com. Imp Exp, Ltda (Jandira, SP, Brasil) e amido modificado (Dextrin Capsul ${ }^{\circledR}$ ) fornecidos pela Ingredion Incorporated (Westchester, IL, Estados Unidos da América (EUA)).

\section{Preparação da emulsão óleo-em-água (O/A)}

Primeiramente, 25,0 g de goma arábica, 37,5 g de amido modificado e $37,5 \mathrm{~g}$ de maltodextrina em $100 \mathrm{~g}$ de solução $(10,11)$ foram hidratados em água desionizada durante aproximadamente 12 horas sob refrigeração $\left(10\right.$ a $\left.12{ }^{\circ} \mathrm{C}\right)$. Em seguida, foram dissolvidos em 450 $\mathrm{mL}$ de água desionizada a $60-70{ }^{\circ} \mathrm{C}$ utilizando o homogeneizador Turratec TE 102 (Tecnal Scientific Equipamentos, Piracicaba, SP, Brasil) a $20000 \mathrm{rpm}$ durante 15 minutos. Após completa solubilização dos materiais de encapsulação, foram adicionados $5 \mathrm{~mL}$ do óleo de semente do maracujá da Caatinga a $18{ }^{\circ} \mathrm{C}$, com velocidade do rotor de $20000 \mathrm{rpm}$ durante 5 minutos, até a obtenção da emulsão $\mathrm{O} / \mathrm{A}$.

\section{Secagem por atomização das micropartículas}

A emulsão $\mathrm{O} / \mathrm{A}$ preparada foi seca por pulverização do MSD 0.5 LABMAQ (Ribeirão Preto, SP, Brasil), com um bocal duplo de fluido de 0,7 $\mathrm{mm}$ de abertura. As condições de operação do atomizador escolhidas após a 
$105^{\circ} \mathrm{C}$ in a conventional greenhouse (Ethik ${ }^{\circledR}$ Technology 402-5D, Vargem Grande Paulista, SP, Brazil) (12).

\section{Physicochemical characterization}

The particle size and zeta potential of samples were evaluated using Zetasizer Nano-ZS system (Malvern Instruments, Malvern, United Kingdom) after 1:10 dilution with water. The average volumetric diameter was measured and the particle size distribution of the powder (span) was calculated according to Eq. (1) (13).

$$
\operatorname{Span}=\left(\frac{d_{90}-d_{10}}{d_{50}}\right)
$$

in which $\mathrm{d}_{90}, \mathrm{~d}_{50}$ and $\mathrm{d}_{10}$ correspond to an average diameter equal to $90 \%, 50 \%$ and $10 \%$ of the cumulative volume, respectively.

\section{Morphology of the microparticles}

The morphology of the microparticles was evaluated by Scanning Electron Microscopy (SEM). The samples were fixed onto a double-sided adhesive tape, pre-fixed to a carrier, the excess being withdrawn after deposition. The microparticles were then coated with gold on a Quorum Q150 ES metallizer from Quorum Technologies Ltd (East Sussex, United Kingdom) and observed in the scanning electron microscope TESCAN VEGA LMH (Tescan, Kohoutovice, Czech Republic). The microscope was operated at $30 \mathrm{kV}$ with magnifications of 500, 1000, 5000 and $10000 \mathrm{x}$.

\section{Results and discussion}

In this work, microparticles of the seed oil of the Caatinga passion fruit produced by spray drying were developed and characterized to study their future applicability in food industry. Modified starch, arabic gum and maltodextrin were used as encapsulating materials.

Concerning the physicochemical characterization of the microparticles, a diameter of $23.1 \pm 0.05 \mu \mathrm{m}$ was observed, which is in agreement with the described particle size for microparticles of other essential oil derived food products produced by spray drying $(6,14)$. Similar results were obtained in the production of microparticles of passion fruit seed oil by spray drying using different wall materials, drying temperatures, and emulsion homogenization methods (15). The scattering of the particles calculated using the span Eq. (1) was realização dos ensaios preliminares, foram: temperatura de entrada de ar de $120 \pm 3{ }^{\circ} \mathrm{C}$, fluxo de ar foi ajustado para $30 \mathrm{~L} \mathrm{~min}^{-1}$ e a entrada de ar foi mantida a 0,50 $\mathrm{L} \mathrm{h}^{-1}$. A pressão do ar comprimido do fluxo de pulverização foi de 2-4 bar. O pó foi armazenado num frasco de vidro âmbar para minimizar possíveis alterações no material, como aglomeração, causada pela adsorção de água e oxidação.

\section{Atividade de água (Aw) e teor de humidade}

A Aw foi medida diretamente das amostras em triplicado no Aqualab 4TE (Meter Group, Pullman, WA, EUA), a uma temperatura controlada de $18 \pm 0,5^{\circ} \mathrm{C}$. O teor de humidade foi avaliado pelo método gravimétrico, em triplicado, a $105{ }^{\circ} \mathrm{C}$ numa estufa convencional (Ethik $^{\circledR}$ Technology 402-5D, Vargem Grande Paulista, SP, Brasil) (12).

\section{Caracterização físico-química}

O tamanho das partículas e o potencial zeta das amostras foram avaliados no equipamento Zetasizer Nano-ZS (Malvern Instruments, Malvern, Reino Unido) após diluição com água 1:10. O diâmetro volumétrico médio foi medido e a distribuição do tamanho de partícula do pó (span) foi calculada de acordo com a Eq. (1) (13).

$$
\text { Span }=\left(\frac{d_{90}-d_{10}}{d_{50}}\right)
$$

em que $\mathrm{d}_{90}, \mathrm{~d}_{50}$ e $\mathrm{d}_{10}$ correspondem a um diâmetro médio igual a $90 \%, 50 \%$ e $10 \%$ do volume acumulado, respetivamente.

\section{Morfologia das micropartículas}

A morfologia das micropartículas foi avaliada por Microscopia Eletrónica de Varredura (MEV). As amostras foram fixadas numa fita adesiva de dupla face, pré-fixada a um suporte, sendo o excesso retirado após a deposição. As micropartículas foram então revestidas com ouro no metalizador Quorum Q150 ES da Quorum Technologies Ltd (East Sussex, Reino Unido) e observadas no microscópio eletrónico de varrimento TESCAN VEGA LMH (Tescan, Kohoutovice, República Checa). O microscópio foi utilizado a $30 \mathrm{kV}$ com ampliações de 500, 1000,5000 e 10 000x.

\section{Resultados e Discussão}

Neste trabalho, foram desenvolvidas e caracterizadas micropartículas do óleo de semente de maracujá da 
low $(1.56 \pm 0.03)$, which indicate a homogeneous distribution (10,13). Costa et al. (27) and Hijo et al. (10) also reported small scatter values 2.06 to 2.83 and 1.61 , respectively, for microparticles of essential oil of oregano produced by spray drying. According to the literature, the diameter of spray-dried particles depends on the atomization method used, the properties of the material, the concentration and viscosity of the encapsulated material and the drying conditions, and the value obtained in this work is typical of the type of atomizer used (double-fluid) (17).

Moreover, the evaluation of the zeta potential presented a value of $-2.58 \mathrm{mV}$ for the microparticles containing the oil seed of the Caatinga passion fruit, which indicate its feasibility for application in several solid food products $(18,19)$ besides the indication of stability, that is the tendency of the microparticles to agglomerate. It is a magnitude of electric charge on the surface of the particle in aqueous medium, where values between -30 to $+30 \mathrm{mV}$ indicate instability and low values indicate systems with a tendency to agglomerate. In order to avoid agglomerations between the microparticles, values outside the range of $\pm 30 \mathrm{mV}(18,19)$ are desirable. Kumar et al. (17) obtained a value of $25.5 \mathrm{mV}$ and justified that the high drying temperature can cause rupture of hydrogen bonds in the structure of the microparticles, which influences the interaction or aggregation as a result of a lower zeta potential. It is known that starch and maltodextrin are polyelectrolytes bearing charged groups such as free COO-groups present in the octenyl succinic chain.

Thus, the negative values of zeta potential confirmed the presence of starch molecules on the oil droplet surface. It can be explained by the maximum utilization of starch molecules and maltodextrin for the coverage of the passion fruit seed oil droplets.

The dried microparticles showed Aw equivalent to 0.10 \pm 0.02 . This value is in agreement with the literature for foods obtained by spray drying (20). This parameter represents an important factor to evaluate the conservation of food, since values of Aw lower than 0.3 hampers the microbial inhibition, giving the food an extended shelf life $(19,20)$. The obtained result for Aw of the prepared microparticles was similar to the values obtained in previous studies, using spray drying for other essential oils, such as for oregano oil (between 0.13 and 0.17 ) (11), tuna oil (between 0.14 and 0.21) (23) and lemon oil (between 0.12 and 0.34) (9).

The moisture content is a parameter related to the organoleptic quality and shelf-life of a product since high moisture contents could contribute for the adhesion of the microparticles (24)by employing Maltodextrin (MD. The average moisture content found was $1.03 \pm$
Caatinga, produzidas por secagem por atomização, para estudar a sua futura aplicabilidade na indústria de alimentos. Para tal, foram utilizados amido modificado, goma arábica e maltodextrina como materiais de encapsulação.

Quanto à caracterização físico-química das micropartículas, elas apresentaram um diâmetro de 23,1 $\pm 0,05$ $\mu \mathrm{m}$, o que está de acordo com o tamanho de partícula descrito para micropartículas de outros produtos alimentares derivados de óleo essencial produzidos por secagem de atomização $(6,14)$. Resultados semelhantes foram obtidos por quem produziu micropartículas de óleo para a semente de maracujá por secagem por atomização usando diferentes materiais de parede, temperaturas de secagem e métodos de homogeneização de emulsão (15). A dispersão das partículas calculada usando o span (Eq. (1)) foi baixa $(1,56 \pm 0,03)$, o que indica uma distribuição homogênea. Costa et al. (27) e Hijo et al. (10) também relataram pequenos valores de dispersão de 2,06 a 2,83 e 1,61, respectivamente, para micropartículas de óleo essencial de orégano produzidas por spray drying. De acordo com a literatura, o diâmetro das partículas secas por atomização depende do método de atomização utilizado, das propriedades do material, da concentração e viscosidade do material encapsulado e das condições de secagem, sendo o valor obtido neste trabalho típico do tipo de atomizador usado (duplo fluido) (16).

Além disso, a avaliação do potencial zeta apresentou um valor de $-2,58 \mathrm{mV}$ para as micropartículas contendo a semente oleaginosa do maracujá da Caatinga, o que indica sua aplicabilidade em diversos alimentos sólidos $(18,19)$ além do indicativo de estabilidade, ou seja, a tendência das micropartículas de aglomerar. É uma grandeza de carga elétrica na superfície da partícula em meio aquoso, valores entre $\pm 30 \mathrm{mV}$ indicam instabilidade e valores baixos indicam sistemas com maior tendência a aglomeração. A fim de se evitar aglomerações entre as micropartículas, é desejável valores fora da faixa de $\pm 30 \mathrm{mV}(18,19)$. Kumar et al. (17) obtiveram valor de $25,5 \mathrm{mV}$ e justificaram que a temperatura alta de secagem pode ocasionar ruptura de pontes de hidrogênio na estrutura das micropartículas, o que influência na interação ou agregação, como resultado de um menor potencial zeta. Sabe-se que o amido e a maltodextrina são polieletrólitos contendo grupos carregados, tais como grupos COO- livres presentes na cadeia octenilsuccínica. Assim, os valores negativos do potencial zeta confirmaram a presença de moléculas de amido na superfície da partícula oleosa. Isso pode ser explicado pela utilização máxima de moléculas de amido e maltodextrina para a cobertura de sementes das micropartículas de óleo de maracujá. 
$0.03 \%$, which is considered an optimal value for microparticles, as according to Hijo et al. (10) the dry powders used in the food industry have a target (maximum) range between 3-4 \% to prevent microbial deterioration. As shown for Aw, the values obtained for moisture content were also similar to the values of another study using the same procedure, namely for oregano oil, where the obtained values varied between 1.3 and 3.65 $\%$ (25). In another study, using the same method and similar encapsulation materials (maltodextrin, modified starch and corn flake) to encapsulate green coffee oil microparticles, the moisture content ranged from 0.41 $\%$ to $2.49 \%$ (26).

Regarding the SEM analysis, the microparticles showed spherical shape (Figure 1). Such shape is characteristic of the encapsulation method and is in agreement with other works that obtained microparticles by spray drying (27). This study showed that the mixture of materials lead to a higher proportion of spherical particles, most likely because these matrices provided elasticity during the drying process $(7,20,28)$ such as coffee oil, into stable and free-flowing powders. Thus the aim of
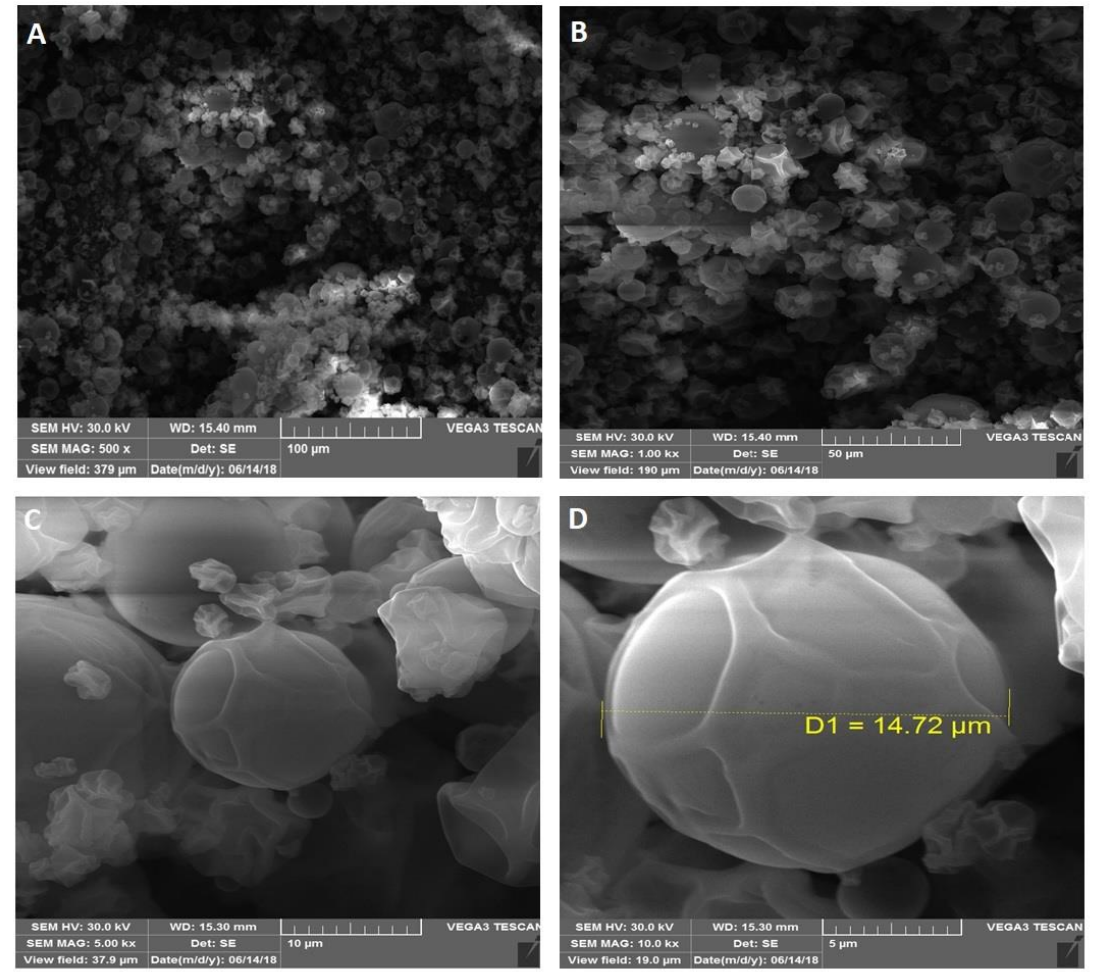

Figure 1/ Figura 1 - SEM Microphotographs of microparticles of the seed oil of the Caatinga passion fruit (A) 500x magnification, (B) 1000x magnification, (C) 5000x magnification, (D) 10000x magnification. / Microfotografia de MEV de semente de maracujá da caatinga. (A) ampliação 500x. (B) ampliação 1000x. (C) ampliação 5000x. (D) ampliação 10000x. 
this study was to evaluate the influence of process conditions on the microencapsulation of coffee oil by spray drying, using gum Arabic as encapsulating agent. The effect of total solid content $(10-30 \%$.

\section{Conclusion}

The Caatinga passion fruit has some interesting phytochemical characteristics which may be relevant for the food, cosmetic and pharmaceutical industries. However, the high content of fatty acids in its essential oil present some challenges for these industries, since it confers low stability to the product. The particles loaded with seed oil from the Caatinga passion fruit by spray drying were successfully produced and characterization showed low values of Aw, moisture content, diameter, spherical shape, and the value of span showed a homogeneous particle size distribution. The results are promising and suitable for future applications in the development of new food products.

\section{Acknowledgements}

Authors would like to thank the support from LMMA sponsored by FAPEMIG (CEX-112-10), SECTES/MG and RQ-MG (FAPEMIG: CEX-RED-00010-14). Ana Júlio and Rita Caparica would like to thank to ALIES for the grant PADDIC 2018-2019.

\section{Conflict of Interests}

The authors declare there are no financial and/or personal relationship that may present a potential conflict of interest. os valores obtidos variaram entre 1,30 e 3,65\% (25). Em outro estudo, o mesmo método e materiais de encapsulação similares (maltodextrina, amido modificado e flocos de milho) para encapsular micropartículas de óleo de café verde, o teor de humidade variou de 0,41 $\%$ a $2,49 \%$ (26).

Em relação à análise do $\mathrm{MEV}$, as micropartículas apresentaram formato esférico (Figura 1). Tal forma é característica do método de encapsulação e está de acordo com outros estudos que obtiveram micropartículas por secagem por atomização (27). Este estudo mostrou que a mistura de materiais leva a uma maior proporção de partículas esféricas, muito provavelmente porque essas matrizes proporcionavam elasticidade durante o processo de secagem $(7,20,28)$.

\section{Conclusão}

O maracujá da Caatinga possui algumas características fitoquímicas interessantes como a atividade antioxidante e seu sabor característico, que podem ser relevantes para as indústrias alimentar, cosmética e farmacêutica. No entanto, o alto teor de ácidos gordos essenciais no seu óleo, apresenta alguns desafios para essas indústrias, uma vez que confere baixa estabilidade ao produto. As partículas com óleo de semente do maracujá da Caatinga encapsulado por secagem por atomização foram produzidas com sucesso e sua caracterização apresentou baixos valores de Aw, humidade, diâmetro, forma esférica, e o valor de span apresentou distribuição homogénea de tamanho de partícula. Os resultados são promissores e adequados para futuras aplicações no desenvolvimento de novos produtos alimentares.

\section{Agradecimentos}

Os autores gostariam de agradecer o apoio da LMMA patrocinada pela FAPEMIG (CEX-112-10), SECTES/ MG e RQ-MG (FAPEMIG: CEX-RED-00010-14). Ana Júlio e Rita Caparica gostariam de agradecer à ALIES pela bolsa PADDIC 2018-2019.

\section{Conflito de Interesses}

Os autores declaram não haver relação financeira e/ou pessoal que possa apresentar um potencial conflito de interesses. 


\section{References/Referências}

1. Andrade JKS, Silva GF da, Barretto LC de O, Santos JAB dos. Estudo da cinética de secagem, extração, caracterização e estabilidade térmica do óleo das sementes de maracujá do mato (Passiflora cincinnata mast.). Rev Gestão, Inovação e Tecnol. 2014;3(5):283-91.

2. Siebra ALA, Oliveira LR, Martins AOBPB, Siebra DC, Albuquerque RS, Lemos ICS, et al. Potentiation of antibiotic activity by Passiflora cincinnata Mast. front of strains Staphylococcus aureus and Escherichia coli. Saudi J Biol Sci [Internet]. 2018;25(1):37-43. Available from: http://dx.doi. org/10.1016/j.sjbs.2016.01.019

3. Wihlem AE, Antoniassi R, Farla-Machado AF, Bizzo HR, Reis SLR, Cenci SA. Diferentes taxas de alimentação de prensa do tipo expeller na eficiência de extração e na qualidade do óleo de semente de maracujá. Ciência Rural. 2014;44(7):1312-8.

4. Lopes RM, Sevilha AC, Faleiro FG, Silva DB Da, Vieira RF, Agostini-Costa T da S. Estudo comparativo do perfil de ácidos graxos em semente de Passifloras nativas do cerrado brasileiro. Rev Bras Frutic. 2010;32(2):498-506.

5. Peanparkdee M, Iwamoto S, Yamauchi R. Microencapsulation: a review of applications in the food and pharmaceutical industries. Rev Agric Sci. 2016;4:56-65.

6. Vishnu K V., Chatterjee NS, Ajeeshkumar KK, Lekshmi RGK, Tejpal CS, Mathew S, et al. Microencapsulation of sardine oil: application of vanillic acid grafted chitosan as a bio-functional wall material. Carbohydr Polym. 2017;174:540-8.

7. Frascareli EC, Silva VM, Tonon R V., Hubinger MD. Effect of process conditions on the microencapsulation of coffee oil by spray drying. Food Bioprod Process. 2012;90(3):413-24.

8. Gharsallaoui A, Roudaut G, Chambin O, Voilley A, Saurel R. Applications of spray-drying in microencapsulation of food ingredients: An overview. Food Res Int. 2007;40(9):1107-21.

9. Campelo PH, Figueiredo J de A, Domingues RZ, Fernandes RV de B, Botrel DA, Borges SV. Use of prebiotic carbohydrate as wall material on lime essential oil microparticles. J Microencapsul. 2017;34(6):535-44.

10. Hijo AACT, Costa JMG da, Silva EK, Azevedo VM, Yoshida MI, Borges SV. Understanding the Influence of Encapsulating Matrix on the Physical and Thermal Properties of Oregano Essential Oil Powder. Int J Hortic Agric. 2017;2(1):1-8.

11. Costa JMG da, Vilela Borges S, Hijo AACT, Silva EK, Reginaldo Marques G, Cirillio MÂ, et al. Matrix structure selection in the microparticles of essential oil oregano produced by spray dryer. J Microencapsul. 2013;30(8):717-27.

12. Association of Official Analytical Chemists. Official methods of analysis. 18 Edição. Latimer GW, editor. Gaithersburg, Maryland: Associationof Official Analytical Chemists; 2005.

13. Da Costa JMG, Silva EK, Toledo Hijo AAC, Azevedo VM, Malta MR, Ferreira Alves JGL, et al. Microencapsulation of Swiss cheese bioaroma by spraydrying: Process optimization and characterization of particles. Powder Technol. 2015;274:296-304.

14. Morales-Medina R, Tamm F, Guadix AM, Guadix EM, Drusch S. Functional and antioxidant properties of hydrolysates of sardine (S. pilchardus) and horse mackerel (T. mediterraneus) for the microencapsulation of fish oil by spray-drying. Food Chem. 2016;194:1208-16.

15. Delfini F de T. Microencapsulação de óleo de semente de maracujá através da secagem por atomização [Internet]. Universidade Estadual de Campinas; 2016. Available from: http://www.repositorio.unicamp.br/handle/REPOSIP/305405

16. Edris AE, Kalemba D, Adamiec J, Piaotkowski M. Microencapsulation of Nigella sativa oleoresin by spray drying for food and nutraceutical applications. Food Chem. 2016;204:326-33.

17. Kumar LRG, Chatterjee NS, Tejpal CS, Vishnu KV, Anas KK, Asha KK, et al. Evaluation of chitosan as a wall material for microencapsulation of squalene by spray drying: Characterization and oxidative stability studies. Int J Biol Macromol. 2017;104:1986-95.

18. Kašpar O, Jakubec M, Štěpánek F. Characterization of spray dried chitosan-TPP microparticles formed by two- and three-fluid nozzles. Powder Technol. 2013;240:31.

19. Estevinho BN, Damas AM, Martins P, Rocha F. Microencapsulation of $\beta$-galactosidase with different biopolymers by a spray-drying process. Food Res Int. 2014;64:134-40.

20. Oliveira MIS, Tonon RV, Nogueira RI, Cabral LMC. Estabilidade da polpa de morango atomizada utilizando diferentes agentes carreadores. Brazilian J Food Technol. 2014;16(4):310-8.

21. Botrel DA, Borges SV, Fernandes RV de B, Antoniassi R, Faria-Machado AF de, Feitosa JP de A, et al. Application of cashew tree gum on the production and stability of spray-dried fish oil. Food Chem. 2016;221:1522-9.

22. Celestino SMC. Princípios de secagem de alimentos. 1a Edição. Embrapa Cerrados. Planaltina, DF, Brasil: Ministério da Agricultura, Pecuária e Abastecimento; 2010. $51 \mathrm{p}$.

23. Bakry AM, Fang Z, Ni Y, Cheng H, Chen YQ, Liang L. Stability of tuna oil and tuna oil/peppermint oil blend microencapsulated using whey protein isolate in combination with carboxymethyl cellulose or pullulan. Food Hydrocoll. 2016;60:559-71.

24. Sanchez-Reinoso Z, Osorio C, Herrera A. Effect of microencapsulation by spray drying on cocoa aroma compounds and physicochemical characterisation of microencapsulates. Powder Technol. 2017;318:110-9.

25. Botrel DA, Vilela Borges S, Victória de Barros Fernandes R, Dantas Viana A, Maria Gomes da Costa J, Reginaldo Marques G. Evaluation of spray drying conditions on properties of microencapsulated oregano essential oil. Int J Food Sci Technol. 2012;47(11):2289-96.

26. Carvalho AGS, Silva VM, Hubinger MD. Microencapsulation by spray drying of emulsified green coffee oil with two-layered membranes. Food Res Int. 2014;61:236-45.

27. Fang Z, Bhandari B. Encapsulation of polyphenols - A review. Trends Food Sci Technol. 2010;21(10):510-23.

28. Fernandes RVDB, Borges SV, Botrel DA. Gum arabic/starch/maltodextrin/inulin as wall materials on the microencapsulation of rosemary essential oil. Carbohydr Polym. 2014;101(1):524-32. 